\title{
Low-dose of organic trace minerals reduced fecal mineral excretion without compromising performance of laying hens
}

\author{
Jialing Qiu' ${ }^{1}$ Xintao Lu', Lianxiang Ma', Chuanchuan Hou', Junna He ${ }^{1}$, Bing Liu ${ }^{1}$, \\ Dongyou $\mathrm{Yu}^{1, *}$, Gang $\mathrm{Lin}^{2}$, and Jiming $\mathrm{Xu}^{3}$
}

\begin{abstract}
* Corresponding Author: Dongyou Yu Tel: +86-571-88982107, Fax: +86-571-8898-2107, E-mail: dyyu@zju.edu.cn
\end{abstract}

'Key Laboratory of Animal Nutrition and Feed in East China of Ministry of Agriculture and College of Animal Sciences, Zhejiang University, Hangzhou 310058, China

2 Institute of Quality Standards and Testing Technology for Agricultural Products, Chinese Academy of

Agricultural Sciences, Beijing 10081, China

${ }^{3}$ College of Life Sciences, Zhejiang University, Hangzhou 310058, China

ORCID

Jialing Qiu

https://orcid.org/0000-0002-3440-7488

Xintao Lu

https://orcid.org/0000-0003-0305-3135

Lianxiang Ma

https://orcid.org/0000-0001-7554-9047

Chuanchuan Hou

https://orcid.org/0000-0001-6731-5611

Junna He

https://orcid.org/0000-0003-1805-2434

Bing Liu

https://orcid.org/0000-0001-8641-4375

Dongyou Yu

https://orcid.org/0000-0002-8350-3126

Gang Lin

https://orcid.org/0000-0003-4106-3107

Jiming Xu

https://orcid.org/0000-0003-3853-6786

Submitted Apr 1, 2019; Revised May 3, 2019; Accepted Jun 17, 2019
Objective: The objective of this study was to investigate the effects of low doses of organic trace minerals (iron, copper, manganese, and zinc) on productive performance, egg quality, yolk and tissue mineral retention, and fecal mineral excretion of laying hens during the late laying period.

Methods: A total of 405 healthy hens (HY-Line White, 50-week-old) were randomly divided into 3 treatments, with 9 replicates per treatment and 15 birds per replicate. The dietary treatments included feeding a basal diet + inorganic trace minerals at commercial levels (CON), a basal diet + inorganic trace minerals at $1 / 3$ commercial levels (ITM), and a basal diet + proteinated trace minerals at $1 / 3$ commercial levels (TRT). The trial lasted for 56 days.

Results: Compared to CON, ITM decreased $(\mathrm{p}<0.05)$ egg production, daily egg mass, albumen height, eggshell strength, yolk Fe concentration, serum alkaline phosphatase activity and total protein, and increased $(\mathrm{p}<0.05)$ egg loss and feed to egg ratio. Whereas with productive performance, egg quality, yolk mineral retention, and serum indices there were no differences ( $>0.05$ ) between CON and TRT. The concentrations of Fe and $\mathrm{Mn}$ in the tissue and tibia were changed notably in ITM relative to CON and TRT. Both ITM and TRT reduced ( $p<$ $0.05)$ fecal mineral excretion compared to CON.

Conclusion: These results indicate that dietary supplementation of low-dose organic trace minerals reduced fecal mineral excretion without negatively impacting hen performance and egg quality.

Keywords: Fecal Mineral Excretion; Laying Hens; Organic Trace Minerals; Performance; Serum Indices; Tissue Mineral Retention

\section{INTRODUCTION}

Trace minerals are essential to animals for growth and production [1]. Iron (Fe) has important physiological functions in animals, including participation in the composition and transport of hemoglobin carriers. As the activator of enzymes, iron is involved in the normal material metabolism and plays an important role in the process of intracellular oxidation [2]. And it is also the electron transporter of many important redox reactions, which involves physiological processes such as gene expression and cell proliferation [2]. As a component of the enzymes, copper $(\mathrm{Cu})$, is directly involved in various metabolic processes. Maintaining the normal metabolism of iron and copper is conducive to the synthesis of hemoglobin and the maturation of red blood cells, meanwhile, copper is also involved in the physiological processes of reproduction, lactation, hair development, pigmentation, and bone development [3]. It is also an indispensable element for forming bone cells, collagen and elastin [3]. As an enzyme activator or component in the metabolism of carbohydrates, proteins, lipids and cholesterol, manganese $(\mathrm{Mn})$ is an essential element for the growth of bone and 
reproduction within the animal [4]. In poultry, manganese is involved in the synthesis of eggshell acidic mucopolysaccharides and glycoproteins, which helps form the organic matrix of the eggshell, and is related to the degree of eggshell crack resistance. In addition, manganese participates in maintaining normal cell metabolism in antioxidant and immune systems [4,5]. Zinc (Zn) is a known necessary component and activating factor of more than 200 species of enzymes within animals, which increase the stability of the membrane structure, participate in a series of chemical reactions in the body, maintain normal metabolism and homeostasis [6]. Zinc can reduce animal oxidative stress and improve the body's immunity, as well as supporting animal breeding, bone growth and development, it is also an important cofactor for carbonic anhydrase, playing an important role in the formation of eggshells [6,7]. Chen et al [8] reported that supplementation of 30 and $45 \mathrm{mg} / \mathrm{kg}$ of zinc in egg-laying ducks' basic diets improved the egg production rate and feed utilization rate, and the antioxidant capacity was higher relatively. Singh et al [9] reported that failure to provide adequate $\mathrm{Zn}$ and $\mathrm{Mn}$ in the diet led to typical leg abnormalities in broilers and reduced serum alkaline phosphatase (AKP) activity.

Most mineral additives currently used in livestock production come from inorganic compounds such as oxides, sulfates, carbonates and phosphates [5]. Antagonisms of dietary inorganic minerals can result in decreased absorption, leading to inorganic mineral salts being over supplied in commercial feeds to prevent deficiencies, which causes concern for the genetic potential of modern breeds and environmental pollution $[10,11]$. Organic trace minerals, which might promote emission reduction, have been shown to be more bioavailable than inorganic mineral salts and could be used at a lower level in animal feed $[12,13]$. Organic trace minerals are stable and not ionized prior to absorption, after entering the digestive tract, they can avoid the precipitation or adsorption by precipitants in the intestinal cavity. What's more, chelating minerals are transported and absorbed as amino acids, therefore, the main benefit of using organic minerals is attributed to greater absorption, because they use the same absorption pathways as the amino acids to which they are bound, decreasing the competition for inorganic trace minerals binding sites, and thus reducing excretion through the bile and feces [9,11-13].

To the authors' knowledge, there are few studies on the application of organic trace minerals in laying hens at present, therefore, the objective of the current experiment was to evaluate the effects of organic trace mineral complex completely replacing inorganic trace minerals on production performance, egg quality, trace minerals' distribution in yolk, tissue, tibia, and excretion of laying hens during the late laying period.

\section{MATERIALS AND METHODS}

\begin{abstract}
Animal care
Experimentation conformed to ethical norms. The use of experimental animals, and the procedures for animal management, and the collection of animal blood and tissues in this research were carried out according to the Institutional Animal Care and the Chinese Guidelines for Animal Welfare and approved by Animal Research Ethics Board of Zhejiang University.
\end{abstract}

\section{Birds and management}

A total of 405 healthy hens (HY-Line White, 50-week-old) with similar body weight and egg-laying rates were used in the 56-day feeding trial. There were 3 dietary treatments and each treatment had 9 replicates with 15 birds per replicate pen. The dietary treatments included feeding a basal diet + inorganic trace minerals at commercial levels $(\mathrm{CON}: \mathrm{Fe}, \mathrm{Cu}$, $\mathrm{Mn}$, and $\mathrm{Zn}$ at 36, 12, 90, and $90 \mathrm{mg} / \mathrm{kg}$, respectively. Which were designed on the basis of average survey data from major feed enterprises in China.), a basal diet + inorganic trace minerals at $1 / 3$ commercial levels (ITM: Fe, $\mathrm{Cu}, \mathrm{Mn}$, and $\mathrm{Zn}$ at $12,4,30$, and $30 \mathrm{mg} / \mathrm{kg}$, respectively) and a basal diet + proteinated trace minerals (Bioplex PP, Alltech Inc., Nicholasville, KY, USA) at $1 / 3$ commercial levels (TRT). The ration of basal supplemented diet was formulated according to NRC [14] recommendation to meet daily nutrient requirement of the hens for maintenance at the later laying period and modified to Chinese standards (NY/T 33-2004) [15]. The commercial trace mineral supplement levels were designed based on the average survey data from the major feed companies in China. The percentage of composition and nutrient level of basal diet are presented in Table 1. The contents of $\mathrm{Fe}, \mathrm{Cu}, \mathrm{Mn}$, and $\mathrm{Zn}$ in the experimental diets were analyzed using inductively coupled plasma mass spectrometry (ICP-MS, model ELAN DRC-e, PerkinElmer Scientific Inc., Billerica, MA, USA), and are listed in Table 2. Hens were raised in the Key Laboratory of Animal Nutrition and Feed in East China of Ministry of Agriculture. In the same chicken house, the experimental hens were raised in a three-tiered three-dimensional cage (3 birds per cage, and each pen measured $45 \mathrm{~cm} \times 30 \mathrm{~cm} \times 30 \mathrm{~cm}$ ) with feed and water ad libitum. Birds were standardized by weight and egg production before starting the experiment. Birds were subjected to $14 \mathrm{~d}$ of adjustment to the experimental diets. Lighting, temperature and humidity were set according to the conventional standards of commercial egg farms.

\section{Performance and egg quality}

During the experiment, eggs were collected at 16:00 p.m. every day. Per replication unit, egg weight and the number of eggs (Including eggs with soft shell, broken shell, and different shape, etc.) produced were recorded daily to calculate the total 
Table 1. Ingredient and nutrient composition of the basal diet

\begin{tabular}{lc}
\hline Items & Content \\
\hline Ingredients (\%) & \\
Corn & 57.00 \\
Soybean meal & 24.00 \\
$\mathrm{CaCO}_{3}$ & 8.50 \\
Wheat middling & 5.00 \\
Emulsified fat powder & 1.50 \\
CaHPO & 1.00 \\
Sodium chloride & 0.30 \\
DL-methionine & 0.12 \\
Lysine-HCl & 0.08 \\
Premix & 2.50 \\
Total & 100.00 \\
Nutrient levels ${ }^{2)}$ & \\
ME (Mcal/kg) & 2.63 \\
CP & 16.45 \\
Lys & 0.89 \\
Met & 0.45 \\
Cys+Met & 0.73 \\
Ca & 3.66 \\
P & 0.56 \\
NPP & 0.35 \\
\hline
\end{tabular}

$M E$, metabolic energy; CP, crude protein; NPP, non-phytic acid phosphorus.

1) The premix without trace minerals provided the following per $\mathrm{kg}$ of the diet: vit $\mathrm{A}, 12,500 \mathrm{IU}$; vit $\mathrm{D}_{3}, 4,125 \mathrm{IU}$; vit $\mathrm{E}, 15 \mathrm{IU}$; vit $\mathrm{K} 2 \mathrm{mg}$; thiamine, $1 \mathrm{mg}$; riboflavin, $8.5 \mathrm{mg}$; calcium pantothenate, $50 \mathrm{mg}$; niacin acid, $32.5 \mathrm{mg}$; pyridoxine, $8 \mathrm{mg}$; folic acid, 5 mg; vit $\mathrm{B}_{12}, 5 \mathrm{mg}$; choline chloride, $500 \mathrm{mg} ; \mathrm{Se}, 0.25 \mathrm{mg} ; \mathrm{l}, 3 \mathrm{mg}$.

${ }^{2)}$ The analyzed $\mathrm{Fe}, \mathrm{Cu}, \mathrm{Mn}$, and $\mathrm{Zn}$ contents in basal diet was 71.9, 7.2, 32.7, and $26.8 \mathrm{mg} / \mathrm{kg}$, respectively. Except for crude protein, calcium and phosphorus levels, all other values were calculated.

egg weight, egg loss and egg production. Feed consumption was recorded every week during the feeding trial to calculate the average daily feed intake (ADFI, g/bird/d). Feed to egg ratio and daily egg mass were calculated according to total feedstuff consumption, total egg weight and egg production at the end of the experiment. Daily egg mass was calculated by

Table 2. Assayed iron, copper, manganese, and zinc content in the experimental $\operatorname{diets}(\mathrm{mg} / \mathrm{kg})$

\begin{tabular}{lcll}
\hline \multirow{2}{*}{ Ingredients } & \multicolumn{3}{c}{ Treatment $^{\text {1) }}$} \\
\cline { 2 - 4 } & \multicolumn{1}{c}{ CON } & \multicolumn{1}{c}{ ITM $^{2)}$} & \multicolumn{1}{c}{ TRT $^{3)}$} \\
\hline Iron & $109.2 \pm 7.8(36)^{4)}$ & $82.8 \pm 6.6(12)$ & $80.6 \pm 3.3(12)$ \\
Copper & $18.6 \pm 2.0(12)$ & $11.2 \pm 1.4(4)$ & $11.1 \pm 1.4(4)$ \\
Manganese & $123.3 \pm 5.5(90)$ & $64.7 \pm 5.9(30)$ & $66.4 \pm 3.4(30)$ \\
Zinc & $113.2 \pm 5.4(90)$ & $58.7 \pm 2.9(30)$ & $57.8 \pm 3.5(30)$ \\
\hline
\end{tabular}

1) CON (control), a basal diet + inorganic trace minerals in commercial level; ITM, a basal diet + inorganic trace minerals in 1/3 commercial level; TRT, a basal diet + proteinated trace minerals in 1/3 commercial level.

2) Inorganic trace minerals provided by Zhejiang Weimeng Feed Technology Co., Ltd., Jiaxing, Zhejiang, China.

${ }^{3)}$ Organic source, proteinated trace minerals (Bioplex Poultry Pack, Alltech Inc., Nicholasville, KY, USA).

${ }^{4)}$ The values in brackets indicate the supplementation of trace minerals added to each group. multiplying the egg production rate (\%) by the average weight of eggs (g) and dividing by 100 [5].

Per replicate, two eggs were collected randomly at the end of 8th week respectively, to assess the following parameters: albumen height, Haugh unit, yolk color, shell strength, and eggshell thickness. Subsequently the egg yolk was stored at $-20^{\circ} \mathrm{C}$ for measuring trace mineral concentrations.

\section{Metabolites and enzyme activities in serum}

On 57th day following the start of treatments, two birds from each replicate were randomly selected to collect blood samples. Blood samples (approximately $5 \mathrm{~mL}$ ) were collected from the wing vein of the bird into individual gel and clot activator tubes before slaughter. Serum was obtained by centrifuging the clotted blood at $2,500 \times \mathrm{g}$ at $4^{\circ} \mathrm{C}$ for $20 \mathrm{~min}$ and the supernatant was collected and stored at $-80^{\circ} \mathrm{C}$ for later determination of metabolites and enzyme activities. Serum samples were analysed photometrically for AKP, glucose (GLU), serum albumin (ALB), total protein (TP), total cholesterol (T-CHO), and triglyceride (TG) in an automated biochemistry analyser using commercial kits (Nanjing Jiancheng Bioengineering Institute, Nanjing, China).

\section{Sample mineral analysis}

Per replicate, one bird was humanely euthanized by cervical dislocation and tissue samples of liver, heart and breast muscle were removed, rinsed with double-distilled water and stored at $-80^{\circ} \mathrm{C}$ for future mineral analysis.

Fat was extracted from tibias using ether after immersing the tibia in a boiling water bath for $30 \mathrm{~min}$ to remove the traces of flesh and cartilages. After washing with double-distilled water, the tibia was dried at $105^{\circ} \mathrm{C}$ for $24 \mathrm{~h}$ [9], and subsequently milled for mineral analysis.

Feces were collected for 3 consecutive days at the end of the trial for each pen. The collection of each $24 \mathrm{~h}$ was kept in polythene sachets and stored at $-20^{\circ} \mathrm{C}$ and pooled at the end of the collection period pending analysis of $\mathrm{Fe}, \mathrm{Cu}, \mathrm{Mn}$, and $\mathrm{Zn}$. Then all fecal samples were dried in a hot-air oven at $65^{\circ} \mathrm{C}$ for $48 \mathrm{~h}$, and ground to pass a 1-mm sieve to achieve homogenous samples for mineral analysis [16].

For mineral analysis, ground samples were diluted up to $50 \mathrm{~mL}$ with double-distilled water after wet ashing with nitric acid and hydrogen peroxide in a microwave digester (model MARS-5, version 194A07, Matthews, NC, USA) [16] for determination of $\mathrm{Cu}, \mathrm{Fe}, \mathrm{Mn}$, and $\mathrm{Zn}$. The $\mathrm{Fe}, \mathrm{Cu}, \mathrm{Mn}$, and $\mathrm{Zn}$ concentrations in yolk, liver, heart, breast muscle and tibia were estimated using ICP-MS (model ELAN DRC-e, PerkinElmer Scientific Inc., USA), while feces were estimated using inductively coupled plasma optical emission spectrometry (ICP-OES, model Optima 8000DV, PerkinElmer Scientific Inc., USA). Bovine liver powder (GBW (E) 080193, National Institute of Standards and Technology, Beijing, China) was 
used as a standard reference material for verifying trace mineral analysis [16].

\section{Statistical analyses}

The data obtained on performance, egg quality, metabolites, and enzyme activities in serum, tissue mineral status, and fecal mineral excretion were analyzed using IBM-SPSS 20.0 software (SPSS. Inc., Chicago, IL, USA). Normally distributed data were analyzed by one-way analysis of variance, and nonnormally distributed data were analyzed by Kruskal-Wallis test. Level of significance was defined as $\mathrm{p}<0.05$. Data were expressed as the mean \pm standard deviation.

\section{RESULTS}

\section{Performance and egg quality}

Performance (Table 3 ) and egg quality (Table 4 ) analysis showed that there were no differences ( $p>0.05$ ) in ADFI, Haugh unit, yolk color, and eggshell thickness among the three treatments. Egg production, daily egg mass and shell strength in CON and TRT were significantly higher $(\mathrm{p}<0.05)$ than those in ITM, whereas egg loss and feed to egg ratio were lower $(\mathrm{p}<0.05)$ than those in ITM. There were no differences ( $p>0.05)$ in egg production, daily egg mass, feed to egg ratio, albumen height, and shell strength between CON and TRT.
While, TRT reduced egg loss compared to CON.

\section{Metabolites and enzyme activities in serum}

Data presented in Table 5 indicates that GLU, ALB, T-CHO, and TG were not significantly different $(\mathrm{p}>0.05)$ among the three treatments. Compared to CON and TRT, ITM decreased alkaline phosphatase activity $(\mathrm{p}<0.05)$ and TP in serum, however, there were no significant differences $(p>0.05)$ in all serum indices between CON and TRT.

\section{Egg-yolk and tissue mineral status}

Data in Table 6 indicate that yolk Fe concentration in ITM was significantly lower $(\mathrm{p}<0.05)$ than that in CON and TRT, however, there was no significant difference between CON and TRT. There were no significant differences $(p>0.05)$ of $\mathrm{Cu}, \mathrm{Mn}$, and $\mathrm{Zn}$ levels in yolk among the three treatments.

As shown in Table 7, the concentrations of $\mathrm{Fe}, \mathrm{Cu}, \mathrm{Mn}$, and Zn decreased significantly $(\mathrm{p}<0.05)$ in the liver in ITM compared to CON. Hens fed ITM diets had lower $(\mathrm{p}<0.05) \mathrm{Mn}$ levels in the heart, compared to CON. The concentrations of $\mathrm{Fe}, \mathrm{Cu}, \mathrm{Mn}$, and $\mathrm{Zn}$ in the breast muscle had no significant differences ( $p>0.05)$ among the three treatments. Whereas all trace mineral concentrations in CON and TRT had no significant differences ( $\mathrm{p}>0.05)$.

Table 3. Effect of experimental diets on productive performance of laying hens

\begin{tabular}{|c|c|c|c|c|}
\hline \multirow{2}{*}{ Parameters } & \multicolumn{3}{|c|}{ Treatments $^{1)}$} & \multirow{2}{*}{$\mathrm{p}$-value } \\
\hline & CON & ITM & TRT & \\
\hline Egg production (\%) & $78.91 \pm 0.26^{b}$ & $76.08 \pm 1.40^{\mathrm{a}}$ & $78.68 \pm 0.75^{b}$ & $<0.05$ \\
\hline Daily egg mass (g/hen/d) & $47.10 \pm 0.87^{b}$ & $45.73 \pm 0.81^{\mathrm{a}}$ & $47.24 \pm 1.14^{b}$ & $<0.05$ \\
\hline Egg loss (\%) & $2.07 \pm 0.10^{b}$ & $2.51 \pm 0.13^{c}$ & $1.91 \pm 0.16^{a}$ & $<0.05$ \\
\hline ADFI (g/hen/d) & $106.52 \pm 1.27$ & $107.81 \pm 1.85$ & $106.41 \pm 1.99$ & 0.181 \\
\hline Feed to egg ratio & $2.26 \pm 0.02^{\mathrm{a}}$ & $2.36 \pm 0.04^{b}$ & $2.25 \pm 0.01^{\mathrm{a}}$ & $<0.05$ \\
\hline
\end{tabular}

ADFI, average daily feed intake.

1) CON (control), a basal diet + inorganic trace minerals in commercial level; ITM, a basal diet + inorganic trace minerals in 1/3 commercial level; TRT, a basal diet + proteinated trace minerals in $1 / 3$ commercial level.

${ }^{a-c}$ On the same line, values with no letter or the same superscripts mean no significant difference $(p>0.05)$, whereas values with different superscript letters are significantly different $(p<0.05)$.

Table 4. Effect of experimental diets on egg quality of laying hens

\begin{tabular}{|c|c|c|c|c|}
\hline \multirow{2}{*}{ Parameters } & \multicolumn{3}{|c|}{ Treatments $^{1)}$} & \multirow{2}{*}{$p$-value } \\
\hline & CON & ITM & TRT & \\
\hline Albumen height (mm) & $8.34 \pm 0.69^{b}$ & $7.52 \pm 1.13^{\mathrm{a}}$ & $8.02 \pm 0.79^{\mathrm{ab}}$ & $<0.05$ \\
\hline Haugh unit & $83.90 \pm 5.14$ & $81.30 \pm 6.19$ & $81.42 \pm 7.30$ & 0.380 \\
\hline Yolk color & $6.00 \pm 0.84$ & $5.67 \pm 0.49$ & $5.83 \pm 0.71$ & 0.361 \\
\hline Shell strength (N) & $35.89 \pm 4.02^{b}$ & $24.87 \pm 3.59^{\mathrm{a}}$ & $35.34 \pm 3.98^{b}$ & $<0.05$ \\
\hline Eggshell thickness (mm) & $0.35 \pm 0.01$ & $0.34 \pm 0.03$ & $0.35 \pm 0.03$ & 0.532 \\
\hline
\end{tabular}

${ }^{1)} \mathrm{CON}$ (control), a basal diet + inorganic trace minerals in commercial level; ITM, a basal diet + inorganic trace minerals in 1/3 commercial level; TRT, a basal diet + proteinated trace minerals in $1 / 3$ commercial level.

a,b On the same line, values with no letter or the same superscripts mean no significant difference $(p>0.05)$, whereas values with different superscript letters are significantly different $(p<0.05)$. 
Table 5. Effect of experimental diets on serum indices of laying hens

\begin{tabular}{|c|c|c|c|c|}
\hline \multirow{2}{*}{ Parameters } & \multicolumn{3}{|c|}{ Treatments $^{1)}$} & \multirow{2}{*}{$p$-value } \\
\hline & CON & ITM & TRT & \\
\hline$\overline{A K P}(U / L)$ & $348.48 \pm 13.02^{b}$ & $295.80 \pm 14.01^{\mathrm{a}}$ & $341.84 \pm 25.72^{b}$ & $<0.05$ \\
\hline $\mathrm{GLU}(\mathrm{mmol} / \mathrm{L})$ & $9.51 \pm 1.56$ & $9.96 \pm 0.98$ & $9.31 \pm 0.80$ & 0.233 \\
\hline$A L B(g / L)$ & $21.76 \pm 1.11$ & $22.55 \pm 2.01$ & $21.98 \pm 1.70$ & 0.342 \\
\hline TP (gprot/L) & $35.83 \pm 3.26^{b}$ & $31.27 \pm 2.64^{a}$ & $34.88 \pm 1.90^{b}$ & $<0.05$ \\
\hline $\mathrm{T}-\mathrm{CHO}(\mathrm{mmol} / \mathrm{L})$ & $1.86 \pm 0.66$ & $2.32 \pm 0.70$ & $1.93 \pm 0.69$ & 0.098 \\
\hline $\mathrm{TG}(\mathrm{mmol} / \mathrm{L})$ & $8.42 \pm 1.16$ & $8.80 \pm 1.26$ & $8.07 \pm 1.10$ & 0.186 \\
\hline
\end{tabular}

AKP, alkaline phosphatase; GLU, glucose; ALB, serum albumin; TP, total protein; T-CHO, total cholesterol; TG, triglyceride.

1) CON (control), a basal diet + inorganic trace minerals in commercial level; ITM, a basal diet + inorganic trace minerals in 1/3 commercial level; TRT, a basal diet + proteinated trace minerals in $1 / 3$ commercial level.

$a, b$ On the same line, values with no letter or the same superscripts mean no significant difference $(p>0.05)$, whereas values with different superscript letters are significantly different $(p<0.05)$.

Table 6. Effect of experimental diets on trace minerals concentration in egg-yolk of laying hens ( $\mathrm{mg} / \mathrm{kg}$, as fresh basis)

\begin{tabular}{lrrrr}
\hline \multirow{2}{*}{ Parameters } & \multicolumn{3}{c}{ Treatments $^{1)}$} & p-value \\
\cline { 2 - 4 } & \multicolumn{1}{c}{ CON } & \multicolumn{1}{c}{ ITM } & TRT & \\
\hline $\mathrm{Fe}$ & $72.10 \pm 3.56^{\mathrm{b}}$ & $58.07 \pm 9.09^{\mathrm{a}}$ & $68.59 \pm 2.87^{\mathrm{b}}$ & $<0.05$ \\
$\mathrm{Cu}$ & $1.87 \pm 0.30$ & $1.70 \pm 0.16$ & $1.69 \pm 0.14$ & 0.170 \\
$\mathrm{Mn}$ & $1.01 \pm 0.22$ & $0.91 \pm 0.09$ & $0.89 \pm 0.17$ & 0.268 \\
$\mathrm{Zn}$ & $40.45 \pm 2.19$ & $40.09 \pm 2.22$ & $40.11 \pm 2.64$ & 0.937 \\
\hline
\end{tabular}

1) CON (control), a basal diet + inorganic trace minerals in commercial level; ITM, a basal diet + inorganic trace minerals in 1/3 commercial level; TRT, a basal diet + proteinated trace minerals in 1/3 commercial level.

${ }^{a, b}$ On the same line, values with no letter or the same superscripts mean no significant difference $(p>0.05)$, whereas values with different superscript letters are significantly different $(p<0.05)$.
Tibia mineral deposition and fecal mineral excretion As shown in Table 8, hens fed ITM diets had reduced Mn and $\mathrm{Zn}$ deposition in tibia, compared to CON and TRT. Both ITM and TRT reduced $(\mathrm{p}<0.05)$ fecal mineral excretion compared to CON (Table 8). ITM decreased $\mathrm{Fe}, \mathrm{Cu}, \mathrm{Mn}$, and Zn by $54.25 \%, 43.73 \%, 35.18 \%$, and $32.31 \%$, respectively, compared to $\mathrm{CON}$, and TRT decreased $\mathrm{Fe}, \mathrm{Cu}, \mathrm{Mn}$, and $\mathrm{Zn}$ excretion by $60.77 \%, 57.99 \%, 52.62 \%$, and $44.14 \%$, respectively.

\section{DISCUSSION}

This study indicates that dietary $\mathrm{Fe}, \mathrm{Cu}, \mathrm{Mn}$, and $\mathrm{Zn}$ supplementation levels and sources do not affect ADFI, egg Haugh unit, yolk color, or eggshell thickness, which is consistent with

Table 7. Effect of experimental diets on tissue (liver, heart, and breast muscle) trace mineral concentrations of laying hens (mg/kg, as fresh basis)

\begin{tabular}{|c|c|c|c|c|}
\hline \multirow{2}{*}{ Parameters } & \multicolumn{3}{|c|}{ Treatments ${ }^{1)}$} & \multirow{2}{*}{$p$-value } \\
\hline & CON & ITM & TRT & \\
\hline \multicolumn{5}{|l|}{ Liver } \\
\hline $\mathrm{Fe}$ & $164.11 \pm 5.09^{b}$ & $119.56 \pm 11.24^{a}$ & $156.00 \pm 16.11^{b}$ & $<0.05$ \\
\hline $\mathrm{Cu}$ & $5.20 \pm 0.80$ & $4.98 \pm 0.58$ & $5.22 \pm 0.66$ & 0.771 \\
\hline $\mathrm{Mn}$ & $5.26 \pm 0.42^{b}$ & $3.68 \pm 0.37^{\mathrm{a}}$ & $5.06 \pm 0.51^{b}$ & $<0.05$ \\
\hline $\mathrm{Zn}$ & $72.59 \pm 9.68^{b}$ & $59.96 \pm 5.86^{a}$ & $67.85 \pm 8.83^{\mathrm{ab}}$ & $<0.05$ \\
\hline \multicolumn{5}{|l|}{ Heart } \\
\hline $\mathrm{Fe}$ & $68.05 \pm 5.18$ & $66.85 \pm 7.90$ & $65.87 \pm 4.95$ & 0.756 \\
\hline $\mathrm{Cu}$ & $6.08 \pm 1.16$ & $5.47 \pm 1.06$ & $5.52 \pm 0.73$ & 0.379 \\
\hline $\mathrm{Mn}$ & $1.09 \pm 0.14^{b}$ & $0.87 \pm 0.03^{\mathrm{a}}$ & $1.03 \pm 0.13^{b}$ & $<0.05$ \\
\hline $\mathrm{Zn}$ & $24.69 \pm 1.66$ & $23.34 \pm 0.98$ & $23.99 \pm 1.52$ & 0.151 \\
\hline \multicolumn{5}{|l|}{ Breast muscle } \\
\hline $\mathrm{Fe}$ & $14.41 \pm 1.98$ & $14.14 \pm 2.35$ & $14.54 \pm 1.73$ & 0.914 \\
\hline $\mathrm{Cu}$ & $0.61 \pm 0.08$ & $0.57 \pm 0.05$ & $0.58 \pm 0.04$ & 0.330 \\
\hline $\mathrm{Mn}$ & $0.24 \pm 0.04$ & $0.23 \pm 0.04$ & $0.22 \pm 0.03$ & 0.362 \\
\hline $\mathrm{Zn}$ & $7.15 \pm 0.35$ & $6.93 \pm 0.41$ & $6.95 \pm 0.42$ & 0.449 \\
\hline
\end{tabular}

1) CON (control), a basal diet + inorganic trace minerals in commercial level; ITM, a basal diet + inorganic trace minerals in 1/3 commercial level; TRT, a basal diet + proteinated trace minerals in 1/3 commercial level.

a,b On the same line, values with no letter or the same superscripts mean no significant difference $(p>0.05)$, whereas values with different superscript letters are significantly different $(p<0.05)$. 
Table 8. Effect of experimental diets on trace minerals concentration in the tibia and feces of laying hens (mg/kg, as air-dry basis)

\begin{tabular}{|c|c|c|c|c|}
\hline \multirow{2}{*}{ Parameters } & \multicolumn{3}{|c|}{ Treatments $^{1)}$} & \multirow{2}{*}{ p-value } \\
\hline & CON & ITM & TRT & \\
\hline \multicolumn{5}{|l|}{ Tibia } \\
\hline $\mathrm{Fe}$ & $82.45 \pm 3.14$ & $80.44 \pm 3.40$ & $80.45 \pm 3.76$ & 0.378 \\
\hline $\mathrm{Cu}$ & $1.29 \pm 0.21$ & $1.40 \pm 0.15$ & $1.32 \pm 0.21$ & 0.481 \\
\hline $\mathrm{Mn}$ & $8.43 \pm 0.51^{b}$ & $6.86 \pm 0.30^{a}$ & $8.36 \pm 0.83^{b}$ & $<0.05$ \\
\hline $\mathrm{Zn}$ & $159.38 \pm 6.01^{b}$ & $136.97 \pm 5.21^{\mathrm{a}}$ & $157.61 \pm 7.18^{b}$ & $<0.05$ \\
\hline \multicolumn{5}{|l|}{ Feces } \\
\hline $\mathrm{Fe}$ & $1,591.24 \pm 81.59^{b}$ & $727.99 \pm 62.30^{a}$ & $624.18 \pm 30.09^{a}$ & $<0.05$ \\
\hline $\mathrm{Cu}$ & $91.25 \pm 1.65^{c}$ & $51.35 \pm 4.83^{b}$ & $38.33 \pm 5.86^{\mathrm{a}}$ & $<0.05$ \\
\hline $\mathrm{Mn}$ & $751.86 \pm 7.33^{c}$ & $487.38 \pm 30.31^{b}$ & $356.25 \pm 9.28^{\mathrm{a}}$ & $<0.05$ \\
\hline $\mathrm{Zn}$ & $615.83 \pm 8.61^{c}$ & $416.87 \pm 12.09^{b}$ & $343.98 \pm 26.52^{\mathrm{a}}$ & $<0.05$ \\
\hline
\end{tabular}

${ }^{1)}$ CON (control), a basal diet + inorganic trace minerals in commercial level; ITM, a basal diet + inorganic trace minerals in 1/3 commercial level; TRT, a basal diet + proteinated trace minerals in $1 / 3$ commercial level.

${ }^{a-c}$ On the same line, values with no letter or the same superscripts mean no significant difference $(p>0.05)$, whereas values with different superscript letters are significantly different $(p<0.05)$.

previous studies $[17,18]$. Tabatabaie et al [19] found that compared to a $\mathrm{Zn}$ un-supplemented group, supplemental organic zinc as Albino-Zn at 25 or $50 \mathrm{mg} / \mathrm{kg}$ decreased feed intake, and increased albumen height and Haugh unit, but $\mathrm{ZnSO}_{4}$ in the same levels had minimal impact. In the present study, organic trace minerals supplemented at $1 / 3$ commercial levels (TRT) had the same results in performance and egg quality compared to inorganic forms at commercial levels (CON). However, inorganic trace mineral (ITM) supplemented at the same dose as TRT decreased egg production, daily egg mass, albumen height and eggshell strength, and increased egg loss and feed to egg ratio compared to $\mathrm{CON}$, which may affect commercial economic benefits.

Trace minerals $\mathrm{Fe}, \mathrm{Cu}, \mathrm{Mn}$, and $\mathrm{Zn}$ are involved in growth and biochemical reactions of animal organisms [1]. Therefore, biochemical indicators and activities of enzymes in the blood can reflect the utilization of trace minerals [20]. Alkaline phosphatase is a zinc-containing enzyme, which is activated by manganese. And it is involved in calcification [21], deficiencies of Mn or Zn may cause subnormal activity of alkaline phosphatase, thus might depress bone and eggshell formation. In this regard, alkaline phosphatase activity in serum may serve as a good tool to compare the biological activities of trace minerals with different supplementation levels and sources. In our study, alkaline phosphatase activity in group ITM decreased by $15.12 \%$ and $13.47 \%$ compared to CON and TRT, respectively, however, TRT had the analogue result as the CON. In an earlier experiment, feeding broilers a basal diet without adding additional trace minerals resulted in typical leg abnormalities and a lower alkaline phosphatase activity in serum, while low doses of organic $\mathrm{Fe}, \mathrm{Cu}, \mathrm{Mn}$, and $\mathrm{Zn}$ in two forms (methionine chelate- or yeast proteinate- based) didn't affect these indicators, compared to inorganic forms at commercial level, which was in line with our results [9].
The contents of GLU, ALB, TP, T-CHO, and TG in serum may evaluate animal health. In our study, the low doses of trace minerals, regardless of inorganic and organic sources, didn't alter these parameters except TP, compared to CON. Although ITM reduced the TP content, TRT showed no significant difference compared to CON. This indicated that low doses of organic trace minerals did not generate a negative impact on the health of laying hens.

The content of trace minerals in animal blood, liver, tibia and other tissues is commonly used as the main index to evaluate the biological efficiency of trace minerals in food [22]. The egg yolk, liver, heart, breast muscle, and tibia were chosen to assay in current study. Fe is stored primarily in liver, spleen, and bone [23], and its absorption rate can be changed by adjusting its amount and form in the feed. Our study found that ITM reduced Fe deposition in egg yolk and liver compared with $\mathrm{CON}$, whereas Fe concentration of all tissues tested were consistent between TRT and CON. But they were inconsistent with earlier literature, which presented that Fe and $\mathrm{Mn}$ concentration in the liver, kidneys, and pancreas of broiler breeders didn't change, regardless of mineral sources and levels [24], which might be due to the differences in type of animal species, experimental phase, or trace mineral level. The supplementation of $\mathrm{Mn}$ in diets can decrease malondialdehyde content in leg muscle by increasing mitochondrial manganese superoxide dismutase activity [25], consequently Mn deficiency might result in leg abnormality [9]. Previous research reported that augmenting dietary $\mathrm{Mn}$ increased eggshell thickness of hens [17]. Therefore, the reduction of manganese deposition in hens may affect their health and productivity. Our study indicated that Mn deposition in liver, heart and tibia of ITM hens were obviously lower than that in both CON and TRT, while no significant difference was found between TRT and CON. Some studies in other species 
have proved that the response to $\mathrm{Zn}$ intake increased linearly and then presented an inflection point when $\mathrm{Zn}$ intake met the requirement, hence tissue $\mathrm{Zn}$ concentrations are commonly used for assessing $\mathrm{Zn}$ requirements [26,27]. Previous literature also reported that tibia $\mathrm{Zn}$ was a sensitive and a suitable index for estimating $\mathrm{Zn}$ requirement of brown-egg laying hens [28]. In the current study, both liver and tibia $\mathrm{Zn}$ concentrations in ITM were significantly lower than that in CON and TRT. Bone is the site of mineral deposition and the change of mineral element content in the tibia can reflect the metabolic status of minerals within the animal [29]. It was interesting that while the reduction of inorganic $\mathrm{Mn}$ and $\mathrm{Zn}$ supplementation in late laying hens might cause abnormal maintenance of bone metabolism, the same low level of organic trace minerals had no adverse effects. Our results about $\mathrm{Fe}, \mathrm{Mn}$, and $\mathrm{Zn}$ deposition indicates that the low dose of organic trace minerals may be more efficient than the same level of inorganic trace minerals, since the organic form is more conducive to the deposition of trace minerals in the body. There were no significant differences in the deposition of $\mathrm{Fe}, \mathrm{Cu}, \mathrm{Mn}$, and $\mathrm{Zn}$ in pectoral muscle, and no significant differences in copper deposition in all tissues, in the current trial. This might be due to muscle being the tissue with less trace mineral deposition, and small changes would be difficult to detect.

Inorganic trace minerals are widely used in livestock production due to their easy accessibility and low cost, but their bioavailability is low. Thereby, in commercial production, producers generally supplement feedstuffs with a large safety margin in order to obtain higher economic benefits, thus causing a greater burden on the environment. It might improve bioavailability when trace minerals are chelated to a ligand, because the likelihood of interaction with other elements or combining with gastrointestinal antagonistic molecules is reduced [30]. Studies on replacing inorganic trace minerals with organic forms partially or entirely in animal feed have shown that organic trace minerals have higher bioavailability and reduced excretion in feces. An earlier study indicated that supplemented inorganic trace mineral with segmental organic modality could enhance the absorption coefficient of these trace minerals [31]. Nollet et al [32] reported that lower levels of organic trace minerals can be added to broiler diet to replace inorganic forms without any negative effects on broiler performance, even increasing feed conversion rate. Further, replacement with organic trace minerals resulted in significantly reduced concentrations of minerals in manure. The results of the current study manifested that both ITM and TRT significantly decreased fecal mineral excretion compared to CON, and TRT was more effective than ITM in reducing $\mathrm{Cu}, \mathrm{Mn}$, and $\mathrm{Zn}$ excretion, which are consistent with previous researches mentioned above. Since organic trace minerals have stable structure, they are absorbed by the intestinal brush border more effectively.

It was concluded from the present investigation that supplemental organic $\mathrm{Fe}, \mathrm{Cu}, \mathrm{Mn}$, and $\mathrm{Zn}$ as mineral proteinates at $1 / 3$ commercial levels was superior to the same level of inorganic minerals. As environmental protection issues are urgently addressed, low doses of trace mineral proteinates can be used in poultry feed, reducing the risk of environmental contamination from fecal minerals without affecting performance and metabolic status of animals. Interestingly, in this study, hens fed organic trace minerals remarkably increased eggshell strength but not increased the eggshell thickness as compared to those fed identical level of inorganics. More research is needed to further explore the effect of organic trace minerals on the microstructure of eggshell. Further research is also needed to investigate the relationship between organic trace minerals and bone development.

\section{CONFLICT OF INTEREST}

We certify that there is no conflict of interest with any financial organization regarding the material discussed in the manuscript.

\section{ACKNOWLEDGMENTS}

This research was funded by the Key Projects of Science and Technology Plan of Zhejiang Province, China (No. 2015C 02022). We are very grateful to Dr. Anne F. Koontz, Dr. Tuoying Ao and Dr. Kristen M. Brennan for revising the language of the article.

\section{REFERENCES}

1. Richards JD, Zhao J, Harrell RJ, Atwell CA, Dibner JJ. Trace mineral nutrition in poultry and swine. Asian-Australas J Anim Sci 2010;23:1527-34. https://doi.org/10.5713/ajas.2010. r.07

2. Han O. Molecular mechanism of intestinal Iron absorption. Metallomics 2011;3:103-9. https://doi.org/10.1039/c0mt00043d

3. Kim YH, Yoo JS, Park JC, et al. Effects of Copper and Zinc sources on growth performance, nutrient digestibility, carcass traits and meat characteristics in finishing pigs. Korean J Food Sci An 2008;28:27-31. https://doi.org/10.5851/kosfa.2008. 28.1.27

4. Aschner JL, Aschner M. Nutritional aspects of Manganese homeostasis. Mol Aspects Med 2005;26:353-62. https://doi. org/10.1016/j.mam.2005.07.003

5. Stefanello C, Santos TC, Murakami AE, Martins EN, Carneiro TC. Productive performance, eggshell quality, and eggshell ultrastructure of laying hens fed diets supplemented with organic trace minerals. Poult Sci 2014;93:104-13. https://doi. org/10.3382/ps.2013-03190 
6. Park SY, Birkhold SG, Kubena LF, Nisbet DJ, Ricke SC. Review on the role of dietary Zinc in poultry nutrition, immunity, and reproduction. Biol Trace Elem Res 2004;101:147-63. https:// doi.org/10.1385/BTER:101:2:147

7. Qian L, Yue X, Hu L, Ma Y, Han X. Changes in diarrhea, nutrients apparent digestibility, digestive enzyme activities of weaned piglets in response to chitosan-zinc chelate. Anim Sci J 2016;87:564-9. https://doi.org/10.1111/asj.12460

8. Chen W, Wang S, Zhang HX, et al. Optimization of dietary Zinc for egg production and antioxidant capacity in Chinese egg-laying ducks fed a diet based on corn-wheat bran and soybean meal. Poult Sci 2017;96:2336-43. https://doi.org/10. 3382/ps/pex032

9. Singh AK, Ghosh TK, Haldar S. Effects of methionine chelateor yeast proteinate-based supplement of copper, iron, manganese and zinc on broiler growth performance, their distribution in the tibia and excretion into the environment. Biol Trace Elem Res 2015;164:253-60. https://doi.org/10.1007/s12011014-0222-2

10. Aksu T, Ozsoy B, Aksu DS, Yoruk MA, Gul M. The effects of lower levels of organically complexed zinc, copper and manganese in broiler diets on performance, mineral concentration of tibia and mineral excretion. Kafkas Univ Vet Fak Derg 2011; 17:141-6.

11.Leeson S, Caston L. Using minimal supplements of trace minerals as a method of reducing trace mineral content of poultry manure. Anim Feed Sci Technol 2008;142:339-47. https://doi. org/10.1016/j.anifeedsci.2007.08.004

12.Liu Y, Ma YL, Zhao JM, Vazquez-Anon M, Stein HH. Digestibility and retention of zinc, copper, manganese, iron, calcium, and phosphorus in pigs fed diets containing inorganic or organic minerals. J Anim Sci 2014;92:3407-15. https://doi.org/ 10.2527/jas.2013-7080

13. Mabe I, Rapp C, Bain MM, Nys Y. Supplementation of a cornsoybean meal diet with manganese, copper, and zinc from organic or inorganic sources improves eggshell quality in aged laying hens. Poult Sci 2003;82:1903-13. https:/doi.org/10.1093/ ps/82.12.1903

14. National Research Council. Nutrient requirements of poultry: 9th Revised Edition. Washington, DC, USA: National Academy Press; 1994.

15.The Ministry of Agriculture of the People's Republic of China. Feeding standard of chicken. Beijing, China; 2004.

16. Liu B, Xiong P, Chen N, et al. Effects of replacing of inorganic trace minerals by organically bound trace minerals on growth performance, tissue mineral status, and fecal mineral excretion in commercial grower-finisher pigs. Biol Trace Elem Res 2016;173:316-24. https://doi.org/10.1007/s12011-016-0658-7

17.Xiao JF, Wu SG, Zhang HJ, et al. Bioefficacy comparison of organic manganese with inorganic manganese for eggshell quality in Hy-Line Brown laying hens. Poult Sci 2015;94:18718. https://doi.org/10.3382/ps/pev138
18.Zhang YN, Wang J, Zhang HJ, Wu SG, Qi GH. Effect of dietary supplementation of organic or inorganic manganese on eggshell quality, ultrastructure, and components in laying hens. Poult Sci 2017;96:2184-93. https://doi.org/10.3382/ps/pew495

19. Tabatabaie MM, Aliarabi H, Saki AA, Ahmadi A, Hosseini Siyar SA. Effect of different sources and levels of zinc on egg quality and laying hen performance. Pak J Biol Sci 2007;10: 3476-8. https://doi.org/10.3923/pjbs.2007.3476.3478

20. McLaren G, Patel K, Said H, Anderson G, Said H. Differentiation-dependent regulation of intestinal iron absorption: cell and molecular mechanisms. FASEB J 2015;291(1_suppl): 669.2.

21.Debernard B, Gherardini M, Lunazzi GC, et al. Biochemical and morphologic evidence that alkaline phosphatase of matrix vesicles is involved in calcification. Bone 1985;6:483.

22. Martin RE, Mahan DC, Hill GM, Link JE, Jolliff JS. Effect of dietary organic microminerals on starter pig performance, tissue mineral concentrations, and liver and plasma enzyme activities. J Anim Sci 2011;89:1042-55. https://doi.org/10.2527/ jas.2009-2384

23. Taschetto D, Vieira SL, Angel CR, et al. Iron requirements of broiler breeder hens. Poult Sci 2017;96:3920-7. https://doi. org/10.3382/ps/pex208

24. Wang G, Liu LJ, Wang ZP, et al. Comparison of inorganic and organically bound trace minerals on tissue mineral deposition and fecal excretion in broiler breeders. Biol Trace Elem Res 2019;189:224-32. https://doi.org/10.1007/s12011-018-1460-5

25.Lu L, Ji C, Luo XG, Liu B, Yu SX. The effect of supplemental manganese in broiler diets on abdominal fat deposition and meat quality. Anim Feed Sci Technol 2006;129:49-59. https:// doi.org/10.1016/j.anifeedsci.2005.12.005

26. Hunt JR, Johnson LK. Dietary protein, as egg albumen: effects on bone composition, zinc bioavailability and zinc requirements of rats, assessed by a modified broken-line model. J Nutr 1992;122:161-9. https://doi.org/10.1093/jn/122.1.161

27. Mohanna C, Nys Y. Effect of dietary zinc content and sources on the growth, body zinc deposition and retention, zinc excretion and immune response in chickens. Br Poult Sci 1999;40: 108-14. https://doi.org/10.1080/00071669987926

28. Qin S, Lu L, Zhang X, et al. An optimal dietary zinc level of brown-egg laying hens fed a corn-soybean meal diet. Biol Trace Elem Res 2017;177:376-83. https://doi.org/10.1007/ s12011-016-0867-0

29.Swiatkiewicz S, Arczewska-Wlosek A, Jozefiak D. Bone quality, selected blood variables and mineral retention in laying hens fed with different dietary concentrations and sources of calcium. Livest Sci 2015;181:194-9. https://doi.org/10.1016/j. livsci.2015.09.011

30.Manangi MK, Vazquez-Anon M, Richards JD, Carter S, Buresh $\mathrm{RE}$, Christensen KD. Impact of feeding lower levels of chelated trace minerals versus industry levels of inorganic trace minerals on broiler performance, yield, footpad health, and litter mineral 
concentration. J Appl Poult Res 2012;21:881-90. https://doi. org/10.3382/japr.2012-00531

31. Mondal S, Haldar S, Saha P, Ghosh TK. Metabolism and tissue distribution of trace elements in broiler chickens' FED diets containing deficient and plethoric levels of copper, manganese, and zinc. Biol Trace Elem Res 2010;137:190-205. https://doi. org/10.1007/s12011-009-8570-z

32. Nollet L, Van der Klis JD, Lensing M, Spring P. The effect of replacing inorganic with organic trace minerals in broiler diets on productive performance and mineral excretion. J Appl Poult Res 2007;16:592-7. https://doi.org/10.3382/japr. 2006-00115 